\title{
Di-(2-ethylhexyl) Phthalate (DEHP) and Uterine Histological Characteristics
}

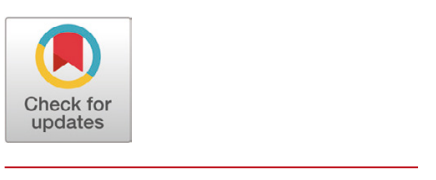

Received: March 3, 2020

Revised: March 7, 2020

Accepted: March 12, 2020

\section{Corresponding author}

Yong-Pil Cheon

Division of Developmental Biology and

Physiology, Dept. of Biotechnology,

Sungshin University, Seoul 02844, Korea.

Tel: +82-2-920-7639

Fax: +82-2-920-2736

E-mail:ypcheon@sungshin.ac.kr

Copyright @ 2020 The Korean Society of Developmental Biology.

This is an Open Access article distributed under the terms of the Creative Commons Attribution Non-Commercial License (http://creativecommons.org/licenses/ by-nc/4.0/) which permits unrestricted non-commercial use, distribution, and reproduction in any medium, provided the original work is properly cited.

ORCID

Yong-Pil Cheon

https://orcid.org/0000-0002-8497-9257

Conflict of interests

None of the authors has any conflicts of interest to disclose.

Acknowledgements

This work was supported by Sungshin University (2018).

Authors' contributions

The article is prepared by a single author.

\author{
${ }^{\dagger}$ Yong-Pil Cheon
}

Division of Developmental Biology and Physiology, Dept. of Biotechnology, Sungshin University, Seoul 02844, Korea

\section{Abstract}

Phthalates have a long industrial history. It is suspected that phthalates and their metabolites have detrimental effects on reproduction and development. They are well-known for their anti-androgenic effects. Several studies have indicated that phthalates and their metabolites are reprotoxic in males and endocrine disruptors. Reproduction and embryogenesis occur in the uterus of female eutherian mammals. A horizontal analytical method is preferred to elucidate the toxic effects of phthalates on human reproduction. Nevertheless, there are vast numbers of known phthalates and not all of their modes of action have been clarified. Di(2-ethylhexyl) phthalate (DEHP) is a commonly used plasticizer and has been the subject of numerous toxicological studies. However, few of these have reported on the toxic effects of DEHP, its metabolites, other phthalates, or mixtures on female reproduction. Acute and high doses of DEHP adversely affect uterine histology. Recently, it was disclosed that chronic exposures to low doses of DEHP have endocrine disruption efficacy. DEHP induces various cellular responses including modulation of the expression and regulation of steroid hormone receptors and transcription and paracrine factors. Uteri do not respond uniformly to DEHP exposure. The phenotypic manifestations and effects on fertility in response to DEHP and its metabolites may vary with species, developmental stage, and generation. Hence, DEHP exposure may histological alter the uterus and induce endometriosis, endometriosis, hyperplasia, myoma, and developmental and reproductive toxicity.

Keywords: Uterus, Histology, Phthalate, Di-(2-ethylhexyl) phthalate (DEHP)

Phthalates (phthalic acids) are synthetic compounds widely used in consumer products such as soft squeeze toys, waxes, paints, solvents, building materials, medical devices, electronics, personal care products, food products, and pharmaceuticals. It is predicted that $\leq 60 \%$ of the global phthalate consumption will be allocated to the aforementioned product categories by 2022 (Chemical Economics Handbook, 2018; Rowdhwal \& Chen, 2018). Phthalates are alkyl esters of orthophthalic acid (o-phthalic acid). They improve the flexibility, transparency, durability, and longevity of plastics. To date, about 40 phthalates have been developed. The most frequently used phthalates include di(2-ethylhexyl) phthalate (DEHP, bis(2-ethylhexyl) phthalate), diisodecyl phthalate (DiDP), and diisononyl phthalate (DiNP) (European Union, 2007; Snejdrova \& Dittrich, 2012; Wang et al., 2019). Phthalates are oily liquids with relatively low volatility. However, they form noncovalent bond with plastics and are readily released to the environment.

Phthalate do not persist in the environment as they undergo rapid biodegradation, photodegradation, and anaerobic degradation (Rudel \& Perovich, 2009). Phthalates exposure occurs 
mainly via ingestion (dietary sources), dermal diffusion, and inhalation (Guo et al., 2014). They are quickly metabolized to their alcohol and phthalic acid constituents (Table 1) and easily excreted (Duty \& Calafat., 2005). However, they have been in use since the 1920s and are ubiquitous by now (Robbins, 2005). Hence, humans and animals have been chronically exposed to environmental phthalates. The toxicological modes of action of phthalates have been evaluated and compared for different organs and species (Kamendulis et al., 2002; Tomonari et al., 2006). Most phthalates have similar modes of action and the overall risk increases when an organism is exposed to combination of several different phthalates simultaneously. The toxic effects of phthalates also vary with developmental stage (Spencer et al., 2012). The severity of phthalate toxicity could increase with life cycle stage and long-term exposure. Certain types of phthalates have been classified as toxicants according to the 2012 United States Environmental Protection Agency (EPA) management plan. These include di-n-butyl phthalate (DBP), diisobutyl phthalate (DIBP), butyl bbenzyl phthalate (BBP), di-n-pentyl phthalate (DnPP), di-(2-ethylhexyl) phthalate (DEHP; bis (2-ethylhexyl) phthalate), di-n-octyl phthalate (DnOP), diisononyl phthalate (DINP), diisodecyl phthalate (DIDP), diethyl phthalate (DEP), benzyl butyl phthalate (BzBP), and dimethyl phthalate (DMP) (Table 1). At this time, plastic manufacturers are in the process of switching to phthalate-free plasticizers.

The toxic effects of phthalates have been analyzed at the single and multiple compound levels (Hannon et al., 2015; Zhou et al., 20b; Cha et al., 2018; Kim et al., 2018; Li et al., 2020). Certain studies reported that low-molecular-weight (LMW) phthalates generally adversely affect human health at lower concentration than high-molecular-weight (HMW) phthalate. However, this observation is inconclusive (Danish, 2013; Ventrice et al., 2013). Phthalates pose a risk of reproductive toxicity for in children aged $\leq 36$ mo who chew objects containing DEHP for 40 $\mathrm{min} /$ day. For this reason, plastic toys, child care articles, and eating vessels and utensils containing components with $1 \%(\mathrm{w} / \mathrm{w})$ DEHP that are readily chewed or sucked were permanently banned for used by children aged $\leq 36$ mo (Austrian Competition \& Consumer Commission). DEHP may cause female infertility, sexual precocity and uterine bleeding and induce epigenetic changes during gestation. Other phthalates besides DEHP also have toxic and endocrine disrupting chemicals (EDCs) effects. In this review, however, we focused on the potential toxic effects of DEHP and other phthalates on uterine histology.

\section{SUGGESTED EFFECTS OF PHTHALATES ON HEALTH AS ENDOCRINE DISRUPTORS}

Phthalates and their metabolites may be toxicants in various animal organ systems (Silva et al., 2011; Bansal et al., 2018; Rowdhwal \& Chen, 2018). They might be associated with metabolic and endocrine disorders such as insulin resistance, diabetes, and obesity. They could also be implicated in immune system dysfunction and breast cancer. However, their toxic effects on reproduction and development in humans are of greatest concern currently. Hence, several national committees (such as. ECHA and NTP-CERHA and research groups continuously evaluate the possible reproductive and developmental toxicities of phthalates (NTP Center for the Evaluation of Risks to Human Reproduction, 2003; Bansal et al., 2018; Rowdhwal \& Chen, 2018; Radke et al., 2019).

Phthalates have demonstrated endocrine, testicular, ovarian, renal, nerve, liver, and heart toxicity and may induce endometriosis (Gillum et al., 2009; Rusyn \& Corton 2012). In zebrafish, a mixture of DEHP and five other phthalates had $\mathrm{LC}_{50}=0.50 \mathrm{ppm}$ and caused embryo mortality and malformation. However, DEHP alone did not induce 50\% mortality in zebrafish embryo even at 
Table 1. Some of the phthalates which are mostly used or known toxicant

\begin{tabular}{|c|c|c|}
\hline Phthalates & Metabolites & Most used, (g/mol), CAS No. \\
\hline Butyl benzyl phthalate (BBP, BBzP) ${ }^{1-8}$ & $\begin{array}{l}\text { Mono-benzyl phthalate (MBzP) } \\
\text { Mono-butyl phthalate (MBP) }\end{array}$ & $\begin{array}{l}\text { Foamed polyvinyl chloride, industrial solvent, } \\
\text { electronics } \\
\text { (HMW; 312.36) } \\
85-68-7\end{array}$ \\
\hline $\begin{array}{l}\text { Dicyclohexyl phthalate (1,2-benzenedicarboxylic } \\
\text { acid dicyclohexylester) (DCHP) }\end{array}$ & Mono-cyclohexyl phthalate cyclohexanol (MCHP) & $\begin{array}{l}\text { Adhesives, } \\
\text { (HMW; 330.40) } \\
\text { 84-61-7 }\end{array}$ \\
\hline Di-n-butyl phthalate (DBP, DnBP) $)^{1-8}$ & $\begin{array}{l}\text { Mono-n-butyl phthalate (MBP, MnBP) } \\
\text { Mono-isobutyl phthalate (MiBP) } \\
\text { Mono(3-carboxypropyl) phthalate (mono- } \\
\text { Carboxyisooctyl phthalate) (MCPP) }\end{array}$ & $\begin{array}{l}\text { Nail polish, adhesives, electronics, dispersions } \\
\text { (LMW; 278.34) } \\
\text { 84-74-2 }\end{array}$ \\
\hline Di-(2-ethylhexyl) phthalate (DEHP) $)^{1-8}$ & $\begin{array}{l}\text { Mono-(2-ethylhexyl) phthalate (mEHP) } \\
\text { Mono-(2-ethyl-5-oxohexyl) phthalate (MEOHP, } \\
\text { 5-oxo-MEHP) } \\
\text { Mono-(2-ethyl-5-hydroxyhexyl) phthalate (MEHHP; } \\
\text { 5-OH-MEHP) } \\
\text { Mono-(2-ethyl-5-carboxypentyl) phthalate } \\
\text { (MECPP; 5-cx-MEPP) } \\
\text { Mono-(2-[(carboxymethyl) hexyl] phthalate (2-cx- } \\
\text { MMHP) } \\
\text { Mono-(3-carboxypropyl) phthalate (mono- } \\
\text { Carboxyisooctyl phthalate) (MCPP) }\end{array}$ & $\begin{array}{l}\text { Plasticizer, polyvinyl chloride, food packages, vinyl } \\
\text { flooring, paints, medical device, electronics } \\
\text { (HMW; 390.56) } \\
117-81-7\end{array}$ \\
\hline Diethyl phthalate (DEP) $)^{7,8}$ & Monoethyl phthalate (mEP) & $\begin{array}{l}\text { Personal care products, animal care products, } \\
\text { electronics, dispersions } \\
\text { (LMW; 222.24) } \\
84-66-2\end{array}$ \\
\hline $\begin{array}{l}\text { 1,2-Benzenedicarboxylic acid, di-C7-11 branched } \\
\text { and linear alkyl esters (Di-C7-11-(linear and } \\
\text { branched)-alkyl phthalate ester; Di-711-phthalate; } \\
\text { Di (heptyl, nonyl, undecyl) phthalate) (DHNUP) }\end{array}$ & & $\begin{array}{l}\text { Plasticizer, PVC, electronics, cosmetics } \\
\text { (HMW; } 418.60) \\
68515-42-4\end{array}$ \\
\hline Di-isobutyl phthalate (DiBP) & $\begin{array}{l}\text { Mono-(carboxynonyl) phthalate (mCNP) } \\
\text { Mono-isobutyl phthalate (mIBP) }\end{array}$ & $\begin{array}{l}\text { Plasticizer, food packages, vinyl flooring, paints, } \\
\text { electronics, dispersions } \\
\text { (LMW; 278.34) } \\
84-69-5\end{array}$ \\
\hline Di-isodecyl phthalate (DiDP) $)^{1-7}$ & $\begin{array}{l}\text { Monobutyl phthalate (mBP) } \\
\text { Monocarboxyisononyl phthalate (MCiNP) } \\
\text { Monohydroxyisodecyol phthalate (MHiDP) } \\
\text { Monooxyisodecy phthalate (MOiDP) } \\
\text { Monoisodecyl phthalate (MIDP) }\end{array}$ & $\begin{array}{l}\text { Plasticizer, electronics, ear plugs } \\
\text { (HMW; 446.66) } \\
26761-40-0 / 68515-49-1\end{array}$ \\
\hline $\begin{array}{l}\text { 1,2-Benzenedicarboxylic acid, di-C6-8-branched } \\
\text { alkyl esters, C7-rich (di-isoheptyl phthalate; bis(5- } \\
\text { methylhexyl) phthalate) (DiHP, DiHeP) }\end{array}$ & & $\begin{array}{l}\text { Plasticizer, electronics, sealant } \\
\text { (HMW; 362.50) } \\
71888-89-6\end{array}$ \\
\hline Di-isononyll phthaltate (DiNP) $)^{1-3,5-7}$ & $\begin{array}{l}\text { Mono(carboxyoctyl) phthalate (MCOP) } \\
\text { Mono-isononyl phthalate (MINP) } \\
\text { Mono(hydroxyisononyl) phthalate (MHINP) } \\
\text { Mono(oxoisononyl) phthalate (MOINP) }\end{array}$ & $\begin{array}{l}\text { Plasticizer, food packages, vinyl flooring, paints, } \\
\text { eraser, electronics } \\
\text { (HMW; } 418.61 \text { ) } \\
28553-12-0 / 68515-48-0\end{array}$ \\
\hline $\begin{array}{l}\text { Di-iso-pentyl phthalate (1,2-benzenedicarboxylic } \\
\text { acid, 1,2-bis(3-methylbutyl) ester) (DiPP, DiPeP) }\end{array}$ & $\begin{array}{l}\text { Mono-isopentyl phthalate (MiPeP) } \\
\text { Mono-3OH-(3-methylbutyl) phthalate }(3 \mathrm{OH}-\mathrm{MiPeP}) \\
\text { Mono-4OH-(3-methylbutyl) phthalate }(4 \mathrm{OH}-\mathrm{MiPeP})\end{array}$ & $\begin{array}{l}\text { Plasticizer, PVC, electronics, propellant } \\
\text { (HMW; 306.40) } \\
605-50-5\end{array}$ \\
\hline $\begin{array}{l}\text { Di (methoxyethyl) phthalate (bis(2-methoxyethyl) } \\
\text { ester) (DMEP) }\end{array}$ & $\begin{array}{l}\text { Ethylene glycol menomethyl ether (EGME) } \\
\text { Methoxyacetic acid (MAA) }\end{array}$ & $\begin{array}{l}\text { Plasticizer, photographic compound, film, } \\
\text { electronics } \\
\text { (LMW; 282.29) } \\
117-82-8\end{array}$ \\
\hline Dimethyl phthalate (DMP) $)^{6-8}$ & Monomethyl phthalate (mMP) & $\begin{array}{l}\text { Insect repellent, fluorescent products, electronics, } \\
\text { dispersions } \\
(\mathrm{LMW} ; 194.18) \\
131-11-3\end{array}$ \\
\hline Di-n-hexyl phthalate (DnHP, DHP, DHEXP) & $\begin{array}{l}\text { n-Hexanol } \\
\text { mono-n-hexyl phthalate (MHxP) }\end{array}$ & $\begin{array}{l}\text { Plasticizer, electronics, footwear } \\
\text { (HMW; 334.45) } \\
84-75-3\end{array}$ \\
\hline Di-n-octyl phthalate (DnOP) $)^{2,3,5,7,8}$ & $\begin{array}{l}\text { Mono-n-octyl phthalate (mOP, MnOP) } \\
\text { Mono-(3-carboxypropyl) phthalate (MCPP) } \\
\text { Mono-n-heptyl phthalate (MHpP) } \\
\text { Mono-n-pentyl phthalate (MPeP) }\end{array}$ & $\begin{array}{l}\text { Plasticizer, PVC, electronics } \\
\text { (HMW; 390.56) } \\
117-84-0\end{array}$ \\
\hline
\end{tabular}


Table 1. Continued

\begin{tabular}{|c|c|c|}
\hline Phthaltates & Metabolites & Most used, (g/mol), CAS No. \\
\hline $\begin{array}{l}\text { Di-n-pentyl phthalate (Diamyl phthalate) } \\
\text { (DnPP, DnPeP, DPENP, DPP), }\end{array}$ & $\begin{array}{l}\text { Mono(3-carboxypropyl) phthalate (mono- } \\
\text { carboxyisooctyl phthalate, (MCPP) } \\
\text { Mono(4-hydroxypentyl) phthalate (MHPP) } \\
\text { Phthalic acid (PA) }\end{array}$ & $\begin{array}{l}\text { Plasticizer, nitrocellulose, electronics, footwear } \\
\text { (HMW; 306.38) } \\
131-18-0\end{array}$ \\
\hline Di (2-propylheptyl) phthalate (DPHP) ${ }^{6}$ & Mono-oxo-propylheptylphthalate (oxo-MPHP) & $\begin{array}{l}\text { Plasticizer, PVC, , cable wire, roofing membranes } \\
\text { (HMW; } 446.66 \text { ) } \\
53306-54-0\end{array}$ \\
\hline $\begin{array}{l}\text { 1,2-Benzenedicarboxylic acid dipentylester, } \\
\text { branched and linear (di-n-propylphthalate; dipentyl } \\
\text { phthalate, branched and linear) (DPP) }\end{array}$ & & $\begin{array}{l}\text { Plasticizer, electronics, footwear } \\
\text { (HMW; } 306.40 \text { ) } \\
84777-06-0\end{array}$ \\
\hline $\begin{array}{l}\text { n-pentyl iso-pentyl phthalate (diamyl phthalate; Di- } \\
\text { n-pentyl phthalte; } 1,2 \text {-bezenedicarboxylid acid, } \\
\text { 1,2-dipentyl ester) (PiPP, nPiPP, DnPP) }\end{array}$ & & $\begin{array}{l}\text { Plasticizer, detergent, electronics } \\
\text { (HMW; 306.40) } \\
131-18-0\end{array}$ \\
\hline
\end{tabular}

${ }^{1}$ California's Proposition 65 as a reproductive and developmental toxicant.

${ }^{2}$ California's AB1108. The bill, if passed, will ban use in the manufacture of any toy or childcare article intended for use by a child under three years of age.

${ }^{3}$ European Union banned as a phthalate softener in the manufacture of toys and childcare articles.

${ }^{4}$ European Union include to Restriction of the use of Hazardous Substances (RoHS).

${ }^{5}$ Japan Toy Safety Standard (ST-2002 Part3).

${ }^{6}$ REACH Regulation (EC)No1907/2006.

${ }^{7}$ Samsung.

${ }^{8}$ TURA, toxics use reduction act.

500 ppm (Chen et al., 2014). In rats, DEHP exposure caused histopathological changes in the thyroid gland and lowered serum T4 levels (Hinton et al., 1986). In humans, MEHP, a metabolite of DEHP, alters free T4 levels (Meeker et al., 2007). DEHP and DnPeP reduced fetal rat testosterone production after uterine exposure (Veeramachaneni \& Klinefelter, 2014; Howdeshell et al., 2015). DEHP induced hepatocellular and Leydig cell tumors and leukemia in rats and mice (David et al., 2000a,b; Carlson, 2010).

Phthalates cross the placental barrier. Exposure during gestation adversely affects juvenile neurodevelopment (Balalian et al., 2019). Phthalates may alter cerebral neural growth and differentiation and have negative neurocognitive and behavioral effects (Owens, 2015). DEHP exposure at $300 \mathrm{mg} / \mathrm{kg}$ BW/d and $750 \mathrm{mg} / \mathrm{kg}$ BW/d inhibited cerebellar granule precursor cell proliferation in male offspring and impaired neuromotor development through Shh signaling (Fu et al., 2019). In male rat progeny, $\mathrm{DnPP}, \mathrm{DnPeP}$ (at high oral dose during pregnancy), or DEHP mixtures caused reproductive tract malformations such as hypospadias, cryptorchidism, and anogenital distance (Hauser \& Calafat, 2005; Howdeshell et al., 2008). During the first trimester, DEHP metabolites cause malformations of the juvenile male reproductive tract (Watkins et al., 2017). Exposure to DEHP or its metabolites during the first trimester is correlated with increases in serum $17 \beta$-estradiol (E2) in males aged 8-14 y (Watkins et al., 2017). DEHP exposure increases insulin resistance by creating imbalances between oxidative stress and antioxidant defenses. DEHP induces oxidative stress in the pancreas (Kim et al., 2013). The negative effects of DEHP exposure on the immune system are more severe during pregnancy than they are at later developmental stages (Holladay \& Smialowicz, 2000). Mono-carboxyisooctyl phthalate (MCPP) is a metabolite of several HMW phthalates and dibutyl phthalate. It is associated with an elevated risk of asthma (Berger et al., 2019). EDC exposure during gestation results in postnatal metabolic disorders and adverse health effects (Lee et al., 2017). DEHP $(100 \mu \mathrm{M})$ enhanced adipogenic differentiation in murine mesenchymal stem cells (Biemann et al., 2012).

Phthalate reprotoxicicity was manifested as phthalate syndrome in male rodents and preterm 
birth in female rodents (Howdeshell et al., 2008; Ferguson et al., 2014; Hannon and Flaws, 2015). Urinary phthalate metabolite concentrations have been associated with spontaneous abortion (miscarriage) and preterm birth (Fromme, 2013; Ferguson et al., 2014). The toxic effects of phthalates may be both transgenerational and ontogenic (Walker, 2011; Zhou et al., 2017). Therefore, reprotoxic phthalates are banned in the EU and other countries (Danish, 2013). Moreover, the concentrations of reprotoxic phthalates in products are limited by law in the United States (Pak \& McCaulery, 2007), South Korea, and other countries (Cho \& Lee, 2018). DEHP, DnBP, DiBP, BBzP, DnPeP, DiPeP, DHNUP, DnHP, and DMEP are classified as category 1B reproductive toxicants under Annex VI to the Classification. Labelling, and Packaging (CLP) Regulation (EC 1272/2008) (HBM4EU). This statute also defined the tolerable daily intake (TDI) of these substances (Lyche et al., 2009).

One aspect of phthalate toxicity is endocrine disruption. The National Institute of Environmental Health Sciences defines EDCs as "chemicals that interfere with the body's endocrine system and produce adverse developmental, reproductive, neurological and immune effects." Phthalates are broadly classified as endocrine disruptors in wildlife and human (Hauser \& Calafat, 2005; Lyche et al., 2009; Su et al., 2014; Bansal et al. 2018; Zamkowska et al., 2018). In humans, phthalate exposure alters steroid levels during gestation, infancy, and adulthood (Hauser \& Calafat, 2005; Lyche et al., 2009; Su et al., 2014). Laboratory animals subjected to EDCs variously presented with early onset of puberty, hindrance of male or female reproductive tract development, interference with the natural functioning of the hormone system, reproductive and genital defects, low adolescent male testosterone, low adult male sperm counts, and impaired uterine development (Agarwal et al., 1986; Dalgaard et al., 2001; Spencer et al., 2012).

DEHP is ubiquitous in the environment. It can be found in the air, water, and soil. It was detected in poultry, cooking oils, and cream-based dairy products (Serrano et al., 2014). A report of the 'Monte Carlo Risk Assessment' program (MCRA 7.0) indicated the concentrations of DEHP and $\mathrm{DiBP}$ were the highest and second highest of the phthalates measured in 550 food products sold on the Belgian market. The consumption of bread contributed to $31.4 \%$ of the total dietary phthalate intake in the general adult population (Sioen et al., 2012). The human body rapidly metabolizes ingested DEHP to MEHP and transforms the latter to 5-OH-MEHP, 5-oxo-MEHP, 5-cx-MEPP, and 2-cx-MMHP (Table 1) (Serrano et al., 2014). DEHP and its metabolites are generally regarded as EDCs and have adverse health effects in at all life stages. The reproductive organs are the main targets of EDC (Hannon et al., 2015). DEHP and its metabolites are generally regarded as EDCs and have adverse health effects at all life stages. The reproductive organs are the main targets of EDCs (Hannon et al., 2015). DEHP and its metabolites bind to estrogen receptors (ERs) and induce ER expression (Cavanagh et al., 2018). In adult males, the main DEHP target is the testis. DEHP causes testicular infertility (Hu et al., 2009). It reduces sperm quality, causes testicular atrophy, and induce Sertoli cell vacuolation and hypospermatogenesis (Hauser, 2006; Street et al., 2018). DEHP downregulates steroidogenic acute regulation protein (StAR) and in utero fetal testicular $17 \alpha$-hydroxylase and cytochrome P450 17A1 mRNAs by direct action on the testis (Kariyazono et al., 2015). Male rats exposed via placental diffusion to DEHP at a dosage range of $100-750 \mathrm{mg} / \mathrm{kg}$ BW/d present with diminished mineralocorticoid receptor expression in the Leydig cells and reduced testosterone levels (Martinez-Arguelles et al., 2009, 2011).

The effects of phthalates on female reproduction are controversial Certain reports suggested that phthalate exposure is correlated with female infertility. Caserta et al. (2013) reported the blood levels of the EDCs whose effects on female reproductive health were evaluated. In rats, DEHP altered the hypothalamus-pituitary-ovary axis and gonadotropin and sex steroid hormone expression (Hirosawa et al., 2006; Ma et al., 2006, 2011; Liu et al., 2014). Estrogenic DEHP 
reduced estrogen levels and inhibited follicle growth in vitro (Kalo et al., 2015) It also diminished primordial follicle recruitment in rodents (Hannon et al., 2014). DEHP administration (2 g/kg BW/d) lowered serum E2. Its metabolites prolonged estrus cycles and suppressed E2 production in granulosa cells vis a receptor-mediated signaling pathways (Lovekamp-Swan \& Davis, 2003). Chronic low-dose DEHP in drinking water induces changes in tissue layer thickness, ER and PR expression, and tissue-specific ER and PR localization (Kim et al., 2018). DEHP treatment alters endometrial epithelial cell proliferation and morphology (Somasundaram et al., 2016). EDCs may directly or indirectly modify endometrial responses to steroid hormones and promote endometriosis (Rier et al., 2002). Certain patients with endometriosis presented with significantly higher DEHP levels than those without it (Cobellis et al., 2003; Reddy et al., 2006; Kim et al., 2011). Caserta et al (2013) reported high blood levels of MEHP, PFOS, and bisphenol-A (BPA) in females presenting with endometriosis. Hence, estrogenic EDCs such as DEHP may cause endometriosis, uterine fibroids, fetal growth restriction, and pregnancy loss (Spencer et al., 2012; Kim et al., 2017).

Phthalates are usually detected along with several of their metabolites in human fluid samples (Jensen et al., 2015). Prenatal phthalate exposure may have multigenerational and transgenerational effects on female reproduction inducing increases in uterine weight, body weight and decreases anogenital distance. Phthalate exposure increased of the number of cystic ovaries in F1 and F2 females. In F3 females, it increased uterine weight and decreased anogenital distance. It also caused fertility complications in F1 and F3 females (Zhou et al., 2017; Li et al., 2020). EDC exposures might increase the risk of breast cancer induction (Maskarinec \& Noh, 2004). The co-relation among DEHP, its metabolites, and breast cancers are controversial (Ahern et al., 2019; Morgan et al., 2017). However, DEHP and its metabolites have strong affinities for progesterone receptor $(\mathrm{PR})$ and there may $82 \%-95 \%$ overlap between PR-interacting residues. Thus, DEHP and its metabolites could disrupt normal PR signaling which results in negative reproductive effects (Sheikh et al., 2016). In T-47D breast cancer cells, DEHP and MEHP induced the PR $\alpha$ expression and nuclear localization. Phthalate treatment caused T-47D cell proliferation without apoptosis (Crobeddu et al., 2019). On the other hand, DEHP enhanced ER $\alpha$-mediated transcriptional activity and decreased ER $\alpha$ protein levels in hypoxic in MCF-7 breast cancer cells (Park et al., 2019).

As DEHP, BBzP, DnBP, and DiBP are endocrine disruptor, they are categorized as substances of very high concern (SVHC) and have been candidates for inclusion in Annex XIV of the REACH regulation since 2017 (HBM4EU). Phthalates are most likely to cause abnormalities in the reproductive systems of animals following exposures during gestation and infancy (Hauser \& Calafat, 2005; Lyche et al., 2009; Su et al., 2014). Female infertility may be associated with EDC exposure. DEHP is a common EDC and classified as a harmful chemical (Wang et al., 2019). Exposure to DEHP increases the bioavailability of other EDCs such as BPA because these agents compete for the same metabolic enzymes (Borman et al., 2017). The uterus is a key organ in mammalian development and the main target organ of EDCs. Furthermore, uterine cells respond to estrogen and progesterone. Until now, data on the possible effects of DEHP on the uterus were very limited. In the next section, we address the effects of DEHP on uterine histology.

\section{DEHP AND UTERINE HISTOLOGY}

Harmonization of the functions of heterogeneous uterine cell types and maintenance of reproductive system homeostasis are vital to successful implantation and reproduction. The uterus comprises luminal and glandular epithelial, stromal, smooth muscle, and uterine-specific or uterine- 
nonspecific immune cells. Harmonization of cell function under the control of the correct levels of sex steroid hormones prepares the uterine environment for normal physiological responses (Cheon et al., 2002). Uterine histology is species-specific and adapted to reproduction patterns. In rodents, Müllerian ducts form bipartite uteri with two horns and two cervical oses.

During radial patterning, uterine morphogenesis establishes the endometrium, myometrium (middle muscular layer consisting of circularly arranged inner and longitudinally arranged outer smooth muscle layers), and perimetrium. The morphogenic processes that occur during the postnatal period include endometrial stroma organization and stratification, myometrium differentiation and growth, and coordinated endometrial gland development. In most eutherian mammals, postnatal endometrial and glandular morphogenesis occurs in species-specific placentation patterns and reproduction patterns. The functional layer of the endometrium is established for implantation and post differentiation (Walker, 2011; Spencer et al., 2012).

Uterine maturation is regulated by estrogen and progesterone. These hormones have specific receptors (ER and PR) that function in the uterus as transcription factors (Okada et al., 2005). $\mathrm{ER} \alpha$ predominantes in all uterine cell types. $\mathrm{ER} \beta$ is expressed at relatively lower expression levels in the uterus and is confined mainly to the subepithelial stromal cells (Wang et al., 2000). PR is strongly localized to the epithelial cells during the diestrus stage and to the stroma during the proestus stage (Ohta et al, 1993; Tan et al., 1999). ERs and PRs are maintained in an inactive state by being bound to an inhibitory protein complex containing heat-shock protein 90 (Hsp90). They are then activated by the binding of estrogen and progesterone (Nardulli \& Shapiro, 1993; Klinge, 2001). Uterine wet weight and volume increase under the influence of estrogen (Shelby et al., 1996). Estrogen promotes endometrial cell proliferation and growth and increases vascular permeability. Progesterone reduces ER levels and promotes cell differentiation and angiogenesis (Ma et al., 2001).

The endometrium undergoes substantial changes during the reproductive cycle. It is composed of surface epithelium, endometrial glands, and the lamina propria. The endometrial cells express ERs and PRs under the regulation of steroid hormones. The luminal and glandular epithelial cells form simple cuboidal or columnar epithelial tissues (Li \& Davis, 2007; Spencer et al., 2012). In rodents, the luminal epithelial, stromal, and myometrial cells proliferate during proestrus, the luminal and glandular epithelial cells are cuboidal, and apoptotic epithelial and stromal cells may be observed (Marcus, 1974; Dharma et al., 2001). During estrus, the luminal epithelial cells differentiate from cuboidal to columnar and develop large cytoplasmic volume. Vacuolar degeneration and apoptosis may be observed in the luminal and glandular epithelia as the uterus reorganizes and prepares for implantation. Apoptotic luminal epithelial cell are observed at this time (Dharma et al., 2001). During metestrus, the epithelial cells are large and columnar but their cytoplasmic volumes are substantially reduced. Glandular apoptosis is relatively less frequent and there are comparatively fewer inflammatory cells in the lamina propria. Apoptotic luminal epithelial, glandular, and stromal cells may be observed (Dharma et al., 2001). During early diestrus, the glandular, stromal, and vascular cells proliferate and increase the thickness of the uterine endometrium. The luminal epithelial cells organize into a single layer of tall columnar cell with basal nuclei. Apoptotic stromal cells can be seen (Dharma et al., 2001).

Estrogen and progesterone tightly regulate endometrial cell proliferation and differentiation (Cheon et al., 2002; Singh et al., 2011). The adverse effects of high estrogen dose are well documented. Estrogen exposure during the perinatal period induce cystic endometrial hyperplasia, squamous metaplasia, adenomyosis, and myometrial and general uterine hypoplasia (Houston et al., 2003). ER $\alpha$ overexpression increases the number of apoptotic cells in the endometrial epithelium and decreases the number of implantation sites (Tomic et al., 2007). It is postulated that estrogenic EDCs have nearly the same effects on the uterus as endogenous estrogen itself. DEHP inhibits E2 
binding to its receptors (Jobling et al., 1995) and induces estrogenic activity via ERs (Cavanagh et al., 2018). The mode of action of DEHP differs among species. Tomonari and colleagues (2006) reported that exposure to $0-100 \mathrm{mg} / \mathrm{kg} \mathrm{BW} / \mathrm{d}$ in marmosets from weaning ( $3 \mathrm{mo}$ ) to sexual maturity (18 mo) did not cause abnormal histological changes. In rats, 1,000 mg/kg BW/d DEHP exposure during gestation days 6-15 reduced uterine weight (Hellwig et al., 1997; Ambe et al., 2019). In contrast, 0-100 mg/kg BW/d DEHP exposure for $30 \mathrm{~d}$ did not have that effect (Somasundaram et al., 2016). Uterine weight was increased by DEHP exposure in drinking water at a concentration of $133 \mu \mathrm{g} / \mathrm{L}$ (Kim et al., 2018).

Uterine horns develop after birth and form an external myometrium surrounding the mesenchymal compartment (Cunha 1976; Kurita, 2011). In rats, DEHP treatment reduced the relative uterine horn diameter (Somasundaram et al., 2016). In endometrial cells, DEHP exposure enhanced comparative MMP-2 and MMP-9 activity, cellular invasiveness, Erk phosporylation, and p21-activated kinase 4 expression (Kim et al., 2015). Uterine gland development is vital to conceptus development in placental mammals (Burton et al., 2002; Gray et al. 2002). Interactions between the epithelium and the stroma in the gland-forming area are critical. They are mediated by steroid hormones, paracrine factors, and the networks that link them (Lubahn et al., 1993; Gray et al., 2000; Taylor et al., 2001; Carpenter et al. 2003; Mericskay et al., 2004; Jeong et al., 2010). The adverse effects of DEHP on uterine gland development and function are controversial. Somasundaram et al (2016) suggested that DEHP treatment lowers the number of endometrial glands and disrupt their structure. However, other researchers reported the opposite results. Richardson et al (2018) showed that $200 \mathrm{mg} / \mathrm{kg}$ BW/d DEHP exposure for $30 \mathrm{~d}$ increased the relative number of endometrial glands. However, it is generally believed that DEHP has toxic effects on the uterus (Kim et al., 2018; Ambe et al., 2019). Chronic low-dose exposure to DEHP induces histological changes. A concentration of $50 \mu \mathrm{g} / \mathrm{L}$ DEHP in drinking water increased the relative number of endometrial glands (Kim et al., 2018).

The uterine mesenchyme directs and specifies the surfacing epithelium. It also organizes the endometrial stroma and promotes myometrial differentiation (Cunha 1976, 1989; Kurita et al., 2001). Intrinsic growth factor systems and the ECM microenvironment mediate epithelialmesenchymal interactions (Spencer et al., 1993; Hu et al., 2004). DEHP treatment at $200 \mu \mathrm{g} /$ $\mathrm{kg} \mathrm{BW/d}$ for $30 \mathrm{~d}$ reduced uterine epithelial cell proliferation (Richardson et al., 2018). Thinning of the uterine layer was observed in rats treated with $0-100 \mathrm{mg} / \mathrm{kg}$ BW/d DEHP for 30 day (Somasundaram et al., 2016). However, chronic low-dose DEHP treatment (133 $\mu \mathrm{g} / \mathrm{L}$ and 1,330 $\mu \mathrm{g} / \mathrm{L}$ in drinking water) increase endometrial thickness in mice (Kim et al., 2018). On the other hand, DEHP may induce myometrial cell proliferation. Chronic administration of $133 \mu \mathrm{g} / \mathrm{L}$ DEHP in drinking water increased relative myometrial thickness (Kim et al., 2018).

Even individual phthalate compounds can influence uterine histology. However, recent studies revealed that phthalate mixtures had similar effects on the uterus. Exposure to an environmentally relevant phthalate mixture (35\% DEP, 21\% DEHP, 15\% DBP, 15\% DiNP, 8\% DiBP, and 5\% BBP) during gestation caused multigenerational alterations in uterine histology (Li et al., 2020). Nevertheless, Li et al (2020) reported that phthalate mixtures did not affect uterine wet weight, endometrium size, number of glands, or inner or outer myometrium thickness in any generation. However, luminal epithelial cell proliferation decreased in the $\mathrm{F} 1$ generation in response to phthalate mixtures. In F1 subjected to $200 \mu \mathrm{g} / \mathrm{kg} / \mathrm{d}$ phthalate mixture, $0.05 \%$ of their luminal epithelial cells were Ki67-positive. Luminal epithelial cell proliferation increased in the F2 generation and $62.88 \%$ of those cells were Ki67-positive. For all generations, the phthalate mixture increased the relative amount of multilayered luminal epithelia. Phthalate mixture exposure during gestation resulted in the formation of large, dilated endometrial glands in all generations. In certain 
animals, these glands penetrated the myometrial layer ( $\mathrm{Li}$ et al., 2020).

It is uncertain whether DEHP causes female infertility. In an animal model, high dose of DEHP impaired female fertility (Schmidt et al., 2012). Recently, however, we investigated the possible that chronic exposures to low-dose DEHP have EDC efficacy in the uterus. However, this treatment did not diminish parental or F1 fertility (Cha et al., 2018; Kim et al., 2018). For women receiving IVF/ICSI treatment, urinary DEHP metabolite levels were not correlated with clinical outcomes in the total population (Hauser et al., 2016; Deng et al., 2020).

DEHP may also induce various cellular responses. At the cellular level, DEHP increases endometrial $\operatorname{ER} \alpha$ and PR proteins levels (Somasundaram et al., 2016). DEHP can induce oxidative stress in endometrial stroma cells (Cho et al., 2015). DEHP decreased ERa protein expression in Ishikawa human endometrial adenocarcinoma cells and slightly decreased hypoxic VEGF secretion (Park et al., 2019). DEHP enhanced myometrial and leiomyomal cell proliferation and antiapoptosis (Kim et al., 2017). DEHP is agonistic to PR (Sheikh et al. 2016). DEHP upregulated uterine $\mathrm{GnRH}$ receptors and hypothalamic $\mathrm{GnRH}$ in pubertal rats (Liu et al., 2016). DEHP induces inflammation mediating peroxisome proliferator-activated receptor gamma (PPAR $\gamma)$ in cultured primary endometrial stroma cells without epithelial-mesenchymal transition (EMT) (Huang et al., 2016).

Estrogen and progesterone have the opposite effects in the paracrine maintenance of uterine histology (Li et al., 2011; Chung et al., 2015). The complexity of steroid hormonal regulation and the roles of various cells in uterine function render it difficult to elucidate the potential effects of DEHP on uterine histology. EDCs may have detrimental effects on reproductive health. Further studies are required to clarify the mechanisms of EDC toxicity in animal models and humans. DEHP causes abnormal histological phenotypes and their associated aberrant cellular responses may play roles in uterine pathogenesis of uterus.

\section{CONCLUSION}

Phthalates have diverse and useful industrial applications. However, certain ubiquitous phthalates such as DEHP are toxic to mammals and the environment. Therefore, numerous international governments have restricted or even banned the use of phthalates. Polyethylene, polypropylen, polyurethane, silicone, and ethylene vinyl acetate have substituted for phthalates in plastic fabrication. Nevertheless, long-term exposure to low levels of residual DEHP and its metabolites such as MEHP may cause endocrine disruption and alter uterine histology and sex hormone receptors in mammals.

EDC exposure at critical period of differentiation in the female reproductive tract might change developmental programming and profoundly influence the outcome of functional reproductive disorders (Norgil Damgaard et al., 2002; Masse et al., 2009; Walker et al., 2011). In model animals, prenatal EDC exposure results in uterine lesions such as altered steroid receptor concentration and responsiveness, persistent gene induction or repression, cystic endometrial hyperplasia, squamous metaplasia, and myometrial and general uterine hypoplasia (Spencer et al., 2012).

DEHP adversely affects adult female uterine histology. DEHP induces various cellular responses such as alteration of the expression and regulation of steroid hormone receptors and transcription factors. However, whether DEHP decreases fertility remains inconclusive. Recent research suggested that like acute and high-concentration DEHP exposures, chronic-low-dose DEHP and environmentally relevant phthalate mixture exposure may modify uterine histology and induce reproductive diseases such as endometriosis, hyperplasia, and myoma. 


\section{REFERENCES}

Agarwal DK, Eustis S, Lamb JC 4th, Reel JR, Kluwe WM (1986) Effects of di (2-ethylhexyl) phthalate on the gonadal pathophysiology, sperm morphology, and reproductive performance of male rats. Environ Health Perspect 65:343-350.

Ahern TP, Broe A, Lash TL, Cronin-Fenton D, Ulrichsen SP, Christiansen PM, Cole BF, Tamimi RM, Sørensen HT, Damkier P (2019) Phthalate exposure and breast cancer incidence: A Danish nationwide cohort study.J Clin Oncol 37:1800-1809.

Ambe K, Sakakibara Y, Sakabe A, Makino H, Ochibe T, Tohkin M (2019) Comparison of the developmental/reproductive toxocity and hepatotoxicity of phthalate esters in rats using an open toxicity data source. J Toxicol Sci 44:245-255.

Austrian Competition \& Consumer Commission [ACCC]. Chemical hazards \& injuries. Accessed from: https://www.productsafety.gov.au/about-us/chemicals/chemical-hazards-injuries. Accessed at February 1, 2020.

Balalian AA, Whyatt RM, Liu X, Insel BJ, Rauh VA, Herbstman J, Factor-Litvak P (2019) Prenatal and childhood exposure to phthalates and motor skills at age 11 years. Environ Res 171:416-427.

Bansal A, Henao-Mejia J, Simmons RA (2018) Immune system: An emerging player in mediating effects of endocrine disruptors on metabolic health. Endocrinology 159:32-45.

Berger K, Eskenazi B, Balmes J, Kogut K, Holland N, Calafat AM, Harley KG (2019) Prenatal high molecular weight phthalates and bisphenol $\mathrm{A}$, and childhood respiratory and allergic outcomes. Peidatr Allergy Immunol 30:36-46.

Biemann R, Navarrete Santos A, Navarrete Santos A, Riemann D, Knelangen J, Blüher M, Koch H, Fisher B (2012) Endocrine disrupting chemicals affect the adipogenic differentiation off mesenchymal stem cells in distinct ontogenetic windows. Biochem Biophys Res Comm 417:747-752.

Borman ED, Foster WG, deCatanzaro D (2017) Concurrent administration of diethylhexyl phthalate reduces the threshold dose at which bisphenol A disrupts blastocyst implantation and cadherins in mice. Environ Toxicol Pharmacol 49:105-111.

Burton GJ, Watson AL, Hempstock JN, Jauniaux E (2002) Uterine glands provide histiotrophic nutrition for the human fetus during the first trimester of pregnancy.J Clin Endocrinol Metab 87:2954-2959.

Carlson KR (2010) Toxicity review of di- $n$-octyl phthalate (DnOP). U.S. Consumer Product Safety Commission, Bethesda, MD.

Carpenter KD, Hayashi K, Spencer TE (2003) Ovarian regulation of endometrial gland morphogenesis and activin-follistatin system in the neonatal ovine uterus. Biol Reprod 69:851860.

Caserta D, Bordi G, Ciagrdo F, Marci R, Rocca CL, Tait S, Bergamasco B, Stecca L, Mantovani A, Guerranti C, Fanello EL, Perra G, Borghini F, Foardi SE, Moscarini M (2013) The influence of endocrine disruptors in a selected population of infertile women. Gynecol Endocrinol 29:444-447.

Cavanagh JA, Trought K, Mitchell C, Northcott G, Tremblay LA (2018) Assessment of endocrine disruption and oxidative potential of bisphenol-A, triclosan, nonylphenol, diethylhexyl phthalate, galaxolide, and carbamazepine, common contaminants of municipal biosolids. Toxicol In Vitro 48:342-349.

Cha S, Jung K, Lee MY, Hwang YJ, Yang E, Lee SH, Jung HI, Cheon YP (2018) Nonmonotonic effects of chronic low-dose di (2-ethylhexyl) phthalate on gonadal weight and reproduction. 
Dev Reprod 22:85-94.

IHS Markit (2018) Plasticizers (Report). In: Chemical Economics Handbook. IHS Markit, London, UK.

Chen X, Xu S, Tan T, Lee ST, Chen SH, Lee FW, Xu SJ, Ho KC (2014) Toxicity and estrogenic endocrine disrupting activity of phthalates and their mixtures. Int J Environ Res Public Health 11:3156-3168.

Cheon YP, Li Q, Xu X, DeMayo FJ, Bagchi IC, Bagchi MK (2002) A genomic approach to identify novel progesterone receptor regulated pathways in the uterus during implantation. Mol Endocrinol 16:2853-28571.

Cho T, Lee H (2018) Current status and tasks of endocrine disruptor management in Korea: Regulation of bisphenol A, phthalate and nonylphenol.J Law Politic Res 18:73-107.

Cho YJ, Park SB, Han M (2015) Di-(2-ethylhexyl)-phthalate induces oxidative stress in human endometrial stromal cells in vitro. Mol Cell Endocrinol 407:9-17.

Chung D, Gao F, Jegga AG, Das SK (2015) Estrogen mediated epithelial proliferation in the uterus is directed by stromal Fgf10 nd Bmp8a. Mol Cell Endocrinol 400:48-60.

Cobellis L, Latini G, De Felice C, Razzi S, Paris I, Ruggieri F, Mazzeo P, Petraglia F (2003) High plasma connetrations of di-(2-ethylhexyl)-phthalate in women with endometriosis. Hum Reprod 18:1512-1515.

Crobeddu B, Ferraris E, Kolasa E, Plante I (2019) Di (2-ethylhexyl) phthalate (DEHP) increases proliferation of epithelial breast cancer cells through progesterone receptor dysregulation. Environ Res 173:165-173.

Cunha GR (1976) Epithelial-stromal interactions in development of the urogenital tract. Int Rev Cytol 47:137-194.

Cunha GR (1989) Development of the urogenital tract. In: Meisami E, Timiras PS (eds), Handbook of Human Growth and Developmental Biology. CRC Press, Boca Raton, FL, pp 247-271.

Dalgaard M, Nellemann C, Lam HR, Sørensen IK, Ladefoged O (2001) The acute effects of mono (2-ethylhexyl) phthalate (MEHP) on testes of prepubertal Wistar rats. Toxicol Lett 122:69-79.

Damgaard NI, Main KM, Toppari J, Skakkebaek NE (2002) Impact of exposure to endocrine disrupters inutero and in childhood on adult reproduction. Best Pract Res Clin Endocrinol Metab 16:289-309.

Danish Environmental Protection Agency [Danish EPA] (2013) Phthalate Strategy. Danish Environmental Protection Agency. Copenhagne, Demark.

David RM, Moore MR, Finney DC, Guest D (2000b) Chronic toxicity of di (2-ethylhexyl) phthalate in mice. Toxicol Sci 58:377-385.

Deng T, Du Y, Wang Y, Teng X, Hua X, Yuan X, Yao Y, Guo N, Li Y (2020) The associations of urinary phthalate metabolites with the intermediate and pregnancy outcomes of women receiving IVF/ICSI treatments: A prospective single-center study. Ecotoxicol Environ Saf 188:109884.

Dharma SJ, Nandedkar TD (2001) Apoptosis in endometrium of mouse during estrous cycle. Indian J Exp Biol 39:218-222.

Duty SM, Calafat AM, Silva MJ, Ryan L, Hauser R (2005) Phthalate exposure and reproductive hormones in adult man. Hum Reprod 20:604-610.

European Chemicals Bureau (2007) European Union Risk Assessment Report: Benzyl Butyl Phthaltate. European Chemicals Bureau, Oslo, Norway.

Ferguson KK, McElrath TF, Ko YA, Mukherjee B, Meeker JD (2014) Variability in urinary phthalate metabolite levels across pregnancy and sensitive windows of exposure for the risk of 
preterm birth. Enciron Int 70:118-124.

Fromme H, Lahrz T, Kraft M, Fembacher L, Dietrich S, Sievering S, Burghardt R, Schuster R, Bolte G, Völkel W. 2013. Phthalates in German daycare centers: Occurrence in air and dust and the excretion of their metabolites by children (LUPE3). Environ Int 61:64-72.

Fu Y, Dong J, You M, Cong Z, Wei L, Fu H, Wang Y, Che J (2019) Maternal di-(2-ethylhexyl) phthalate exposure inhibits cerebellar granule precursor cell proliferation via down-regulation the Shh signaling pathway in male offspring. Chemosphere 215:313-322.

Gillum N, Karabekian Z, Swift LM, Brown RP, Kay MW, Sarvazyan N (2009) Clinically relevant concentrations of di (2-ethylhexyl) phthalate (DEHP) uncouple cardiac syncytium. Toxicol Appl Pharmacol 236:25-38.

Gray CA, Bartol FF, Taylor KM, Wiley AA, Ramsey WS, Ott TL, Bazer FW, Spencer TE (2000) Ovine uterine gland knock-out model: Effects of gland ablation on the estrous cycle. Biol Reprod 62:448-456.

Gray CA, Burghardt RC, Johnson GA, Bazer FW, Spencer TE (2002) Evidence that absence of endometrial gland secretions in uterine gland knockout ewes compromises conceptus survival and elongation. Reproduction 124:289-300.

Guo Y, Wang L, Kannan K (2014) Phthalates and parabens in personal care products from China: Concentrations and human exposure. Arch Environ Contam Toxicol 66:113-119.

Hannon PR, Brannick KE, Wang W, Flaws JA (2015) Mono (2-ethylhexyl) phthalate accelerates early folliculogenesis and inhibits steroidogenesis in cultured mouse whole ovaries and antral follicles. Biol Reprod 92:120.

Hannon PR, Peretz J, Flaws JA (2014) Daily exposure to di (2-ethylhexyl) phthalate alters estrous cyclicity and accelerates primordial follicle recruitment potentially via dysregulation of the phosphatidylinositol 3-kinase signaling pathway in adult mice. Biol Reprod 90:136.

Hauser R (2006) The environment and male fertility: Recent research on emerging chemicals and semen quality. Semin Reprod Med 24:156-167.

Hauser R, Calafat AM (2005) Phthalates and human health. Occup Environ Med 62:806-818.

Hauser R, Gaskins AJ, Souter I, Smith KW, Dodge LE, Ehrlich S, Meeker JD, Calafat AM, Williams PL (2016) Urinary phthalate metabolite concentrations and reproductive outcomes among women undergoing in vitro fertilization: Results from the EARTH study. Environ Health Perspect 124:831-839.

HBM4EU (2020) HBM4EU priority substance group: Phthalates \& hexamoll dinch. in: Scoping Document ( $1^{\text {st }}$ round of prioritization).v3.1. HBM4EU, Dessau-Rosslau, Germany.

Hellwig J, Freudenberger H, Jäckh R (1997) Differential prenatal toxicity of branched phthalate esters in rats. Food Chem Toxicol 35:501-512.

Hinton RH, Mitchell FE, Mann A, Chescoe D, Price SC, Nunn A, Grasso P, Bridges JW (1986) Effects of phthalic acid esters on the liver and thyroid. Environ Health Perspect 70:195-210.

Hirosawa N, Yano K, Suzuki Y, Sakamoto Y (2006) Endocrine disrupting effect of di-(2ethylhexyl) phthalate on female rats and proteome analyses of their pituitaries. Proteomics 6:958-971.

Holladay SD, Smialowicz RJ (2000) Development of the murine and human immune system: Differential effects of immunotoxicants depend on time off exposure. Environ Health Perspect 108:463-473.

Houston KD, Copland JA, Broaddus RR, Gottardis MM, Fischer SM, Walker CL (2003) Inhibition of proliferation and estrogen receptor signaling by peroxisome proliferator: Activated receptor gamma ligands in uterine leiomyoma. Cancer Res 63:1221-1227.

Howdeshell KL, Rider CV, Wilson VS, Furr JR, Lambright CR, Gray LE Jr. (2015) Dose addition 
models based on biologically relevant reductions in fetal testosterone accurately predict postnatal reproductive tract alterations by a phthalate mixture in rats. Toxicol Sic 148:488-502.

Howdeshell KL, Wilson VS, Furr J, Lambright CR, Rider CV, Blystone CR, Hotchkiss AK, Gray LE Jr. 2008. A mixture of five phthalate esters inhibits fetal testicular testosterone production in the Sprague-Dawley rat in a cumulative, dose-additive manner. Toxicol Sci 105:153-165.

Hu GX, Lian QQ Ge RS, Hardy DO, Li XK. 2009. Phthalate-induced testicular dysgenesis syndrome: Leydig cell influence. Trend Endocrinol Metabol 20:139-145.

Hu J, Zhang X, Nothnick WB, Spencer TE. 2004. Matrix metalloproteinases and their tissue inhibitors in the developing neonatal mouse uterus. Biol Reprod 71:1598-1604

Huang Q, Zhang H, Chen YJ, Chi YL, Dong S. 2016. The inflammation response to DEHP through PPAR $\gamma$ in endometrial cells. Int J Environ Res Public Health 13:318.

Jensen MS, Anand-Ivell R, Nørgaard-Pedersen B, Jönsson BA, Bonde JP, Hougaard DM, Cohen A, Lindh C, Ivell R, Toft G. 2015. Amniotic fluid phthalate levels and male fetal gonad function. Epidemiology 26:91-99.

Jeong JW, Kwak I, Lee KY, Kim TH, Large MJ, Stewart CL, Kaestner KH, Lydon JP, DeMayo FJ. 2010. Foxa2 is essential for mouse endometrial gland development and fertility. Biol Reprod 83:396-403.

Jobling S, Reynolds T, White R, Parker MG, Sumpter JP. 1995. A variety of environmentally persistent chemicals, including some phthalate plasticizers, are weakly estrogenic. Environ Health Respect 103:582-587.

Kalo D, Hadas R, Furmanetal O, Ben-Ari J, Maor Y, Patterson DG, Tomey C, Roth Z. 2015. Carryover effects of acute DEHP exposure on ovarian function and oocyte developmental competence in lactating cows. PLoS ONE 10:e0130896.

Kamendulis L, Isenberg JS, Smith JH, Pugh Jr G, Lington AW, Klauning JE. 2002. Comparative effects of phthalate monoesters on gap junctional intercellular communication and peroxisome proliferation in rodent and primate hepatocytes. J Toxicol Environ Health A 65:569-588.

Kariyazono Y, Taura J, Hattori Y, Ishii Y, Narimatsu S, Fujimura M, Takeda T, Yamada H. 2015. Effect of in utero exposure to endocrine disruptors on fetal steroidogenesis governed by the pituitary-gonad axis: A study in rats using different ways of administration. J Toxicol Sci 40:909-916.

Kim J, Cha S, Lee MY, Hwang YJ, Yang E, Ryou C, Jung HI, Cheon YP. 2018. Chronic low-dose nonylphenol or di-(2-ethylhexyl) phthalate has a different estrogen-like response in mouse uterus. Dev Reprod 22:379-391.

Kim JH, Kim SH, Oh YS, Ihm HJ, Chae HD, Kim CH, Kang BM. 2017. In vitro effects of phthalate esters in human myometrial and leiomyoma cells and increased urinary level of phthalate metabolite in women with uterine leiomyoma. Fertil Steril 107:1061-1069.

Kim JH, Park HY, Bae S, Lim YH, Hong YC. 2013. Diethylhexyl phthalates is associated with insulin resistance via oxidative stress in the elderly: A panel study. PLoS ONE 8:e71392.

Kim SH, Cho S, Ihm HJ, Oh YS, Heo SH, Chun S, Im H, Chae HD, Kim CH, kang BM. 2015. Possible role of phthalate in the pathogenesis of endomeriosis: In vitro, animal, and human data. J Clin Endocrinol Metab 100:1502-1511.

Kim SH, Chun S, Jang JY, Chae HD, Kim CH, Kang BM. 2011. Increased plasma levels of phthalte esters in women with advanced-stage endometriosis: A prospective case-control study. Fertil Steril 95:357-359.

Klinge CM. 2001. Estrogen receptor interaction with estrogen response elements. Nucleic Acids Res 29:2905-2919.

Kurita T. 2011. Normal and abnormal epithelial differentiation in the female reproductive tract. 
Differentiation 82:117-126.

Kurita T, Cooke PS, Cunha GR. 2001. Epithelial-stromal tissue interaction in paramesonephric (Mullerian) epithelial differentiation. Dev Biol 240:194-211.

Lee S, Martinez-Arguelles DB, Campioli E, Papadopoulos V (2017) Fetal exposure to low levels of the plasticizer DEHP predisposes the adult male adrenal gland to endocrine disruption. Endocrinology 158:304-318.

Li K, Liszka M, Zhou C, Brehm E, Flaws JA, Nowak RA (2020) Prenatal exposure to a phthalate mixture leads to multigenerational and transgenerational effects on uterine morphology and function in mice. Reprod Toxil 93:178-190.

Li Q, Kannan A, DeMayo FJ, Lydon JP, Cooke PS, Yamagishi H, Srivastava D, Bagchi MK, Bagchi IC (2011) The antiproliferative action of progesterone in uterine epithelium is mediated by Hand2. Science 331:912-916.

Li S, Davis B (2007) Evaluating rodent vaginal and uterine histology in toxicity studies. Birth Defects Res B Dev Reprod Toxicol 80:246-252.

Liu T, Jia Y, Zhou L, Wang Q, Sun D, Xu J, Wu J, Ghen H, Xu F, Ye L (2016) Effects of di-(2ethylhexyl) phthalate on the hypothalamus: Uterus in pubertal female rats. Int J Environ Res Public Health 13:1130.

Liu T, Li N, Zhu J, Yu G, Guo K, Zhou L, Zheng D, Qu X, Huang J, Chen X, Wang S, Ye L (2014) Effects of di-(2-ethylhexyl) phthalate on the hypothalamus-pituitary-ovarian axis in adult female rats. Reprod Toxicol 46:141-147.

Lovekamp-Swan T, Dais BJ (2003) Mechanisms of phthalate ester toxicity in the female reproductive system. Environ Health Perspect 111:139-145.

Lubahn DB, Moyer JS, Golding TS, Couse JF, Korach KS, Smithies O (1993) Alteration of reproductive function but not prenatal sexual development after insertional disruption of the mouse estrogen receptor gene. Proc Natl Acad Sci USA 90:11162-11166.

Lyche JL, Gutleb AC, Bergman Å, Eriksen GS, Murk ATJ, Ropstad E, Saunders M, Skaare JU (2009) Reproductive and developmental toxicity of phthalates.J Toxicol Environ Health B Crit Rev 12:225-249.

Ma M, Kondo T, Ban S, Umemura T, Kurahashi N, Takeda M, Kishi R (2006) Exposure of prepubertal female rats to inhaled di (2-ethylhexyl) phthalate affects the onset of puberty and postpubertal reproductive functions. Toxicol Sci 93:164-171.

Ma M, Zhang Y, Pei X, Duan Z (2011) Effects of di-(2-ethylhexyl) phthalate exposure on reproductive development and PPARs in prepubertal female rats.J Hyg Res 40:688-692.

Ma W, Tan J, Matsumoto H, Robert B, Abrahamson DR, Das SK, Dey SK (2001) Adult tissue angiogenesis: Evidence for negative regulation by estrogen in the uterus. Mol Endocrinol 15:1983-1992.

Marcus GJ (1974) Mitosis in the rat uterus during the estrous cycle, early pregnancy, and early pseudopregnancy. Biol Reprod 10:447-452.

Martinez-Arguelles DB, Culty M, Zirkin BR, Papadopoulos V (2009) In utero exposure to di(2-ethylhexyl) phthalate decreases mineralocorticoid receptor expression in the adult testis. Endocrinology 150:5575-5585

Martinez-Arguelles DB, Guichard T, Culty M, Zirkin BR, Papadopoulos V (2011) In utero exposure to the antiandrogen di-(2-ethylhexyl) phthalate decreases adrenal aldosterone production in the adult rat. Biol Reprod 85:51-61.

Maskarinec G, Noh JJ (2004) The effect of migration on cancer incidence among Japenese in Hawaii. Ethn Dis 14:431-439.

Massé J, Watrin T, Laurent A, Deschamps S, Guerrier D, Pellerin I (2009) The developing female 
genital tract: From genetics to epigenetics. Int J Dev Biol 53:411-424.

Meeker JD, Calafat AM, Hauser R (2007) Di (2-ethylhexyl) phthaltate metabolites may alter thyroid hormone levels in men. Environ Health Perspet 115:1029-1034.

Mericskay M, Kitajewski J, Sassoon D (2004) Wnt5a is required for proper epithelial-mesenchymal interactions in the uterus. Development 131:2061-2072.

Morgan M, Deoraj A, Felty Q, Roy D (2017) Environment estrogen-like endocrine disrupting chemicals and breast cancer. Mol Cell Endocrinol 457:89-102.

Nardulli AM, Shapiro DJ (1993) DNA bending by nuclear receptors. Receptor 3:247-255.

NTP Center for the Evaluation of Risks to Human Reproduction (2003) NTP-CERHR monograph on the potential human reproductive and developmental effects of di-n-hexyl phthalate (DNHP). NIH Publication No. 03-4489. National Toxicology Program U.S. Department of Health and Human Services, Research Triangle Park, NC.

Ohta Y, Sato T, Iguchi T (1993) Immunocytochemical localization of progesterone receptor in the reproductive tract of adult female rats. Biol Reprod 48:205-213.

Okada A, Sato T, Ohta Y, Iguchi T (2005) Sex steroid hormone receptors in the developing female reproductive tract of laboratory rodents. J Toxicol Sci 30:75-89.

Owens M (2015) Phthalates: Health Effects, Detection and Exposure Prevention. Nova Science, New York, NY.

Pak VM, McCauley LA (2007) Risks of phthalate exposure among the general population: Implications for occupational health nurses. AAOHN J 55:12-17.

Park C, Lee J, Kong B, Park J, Song H, Choi K, Guon T, Lee Y (2019) The effects of bisphenol A, benzyl butyl phthalate, and di (2-ethylhexyl) phthalate on estrogen receptor alpha in estrogen receptor-positive cells under hypoxia. Environ Pollut 248:774-781.

Radke EG, Galizia A, Thayer KA, Cooper GS (2019) Phthalate exposure and metabolic effects: A systematic review of the human epidemiological evidence. Environ Int 132:104768.

Reddy BS, Rozati R, Reddy BV, Raman NV (2006) Association of phthalate esters with endometriosis in Indian women. BJOG 113:515-520.

Richardson KA, Hannon PR, Johnson-Walker YJ, Myint MS, Flaws JA, Nowak RA (2018) Di (2-ethylhexyl) phthalate (DEHP) alters proliferation and uterine gland numbers in the uteri of adult exposed mice. Reprod Toxicol 77:70-79.

Rier S, Foster WG (2002) Environmental dioxins and endometriosis. Toxicol Sci 70:161-170.

Robbins WA (2005) Adverse effects of exposure to phthalates: Communicating risks to workers. AAOHN J 53:59-62.

Rowdhwal SSS, Chen J (2018) Toxic effects of di-2-ethylhexyl phthalate: An overview. Biomed Res Int 2018:1750368.

Rudel RA, Perovich LJ (2009) Endocrine disrupting chemicals in indoor and outdoor air. Atmos Environ 43:170-181.

Rusyn I, Corton JC (2012) Mechanistic considerations for human relevance of cancer hazard of di (2-ethylhexyl) phthalate. Mutat Res 750:141-158.

Schmidt JS, Schaedlich K, Fiandanese N, Pocar P, Fischer B (2012) Effects of di (2-ethylhexyl) phthalate (DEHP) on female fertility and adipogenesis in $\mathrm{C} 3 \mathrm{H} / \mathrm{N}$ mice. Environ Health Perspect 120:1123-1129.

Serrano SE, Braun J, Trasande L, Dills R, Sathyanarayana S (2014) Phthalates and diet: A review of the food monitoring and epidemilogy data. Environ Health 13:43.

Sheikh IA, Abu-Elmagd M, Turki RF, Damanhouri GA, Beg MA, Al-Qahtani M (2016) Endocrine disruption: In silico perspectives of interactions of di-(2-ethylhexyl) phthalae and its five major metabolites with progesterone receptor. BMS Struct Biol 16:16. 
Shelby MD, Newbold RR, Tully DB, Chae K, Davis VL (1996) Assessing environmental chemicals for estrogenicity using a combination of in vitro and in vivo assays. Environ Health Perspect 104:1296-1300.

Silva MJ, Furr J, Samandar E, Preau JL Jr, Gray LE Needham LL, Calafat AM (2011) Urinary and serum metabolites of di-n-pentyl phthalate in rats. Chemosphere 82:431-436.

Singh M, Chaudhry P, Asselin E (2011) Bridging endometrial receptivity and implantation: Network of hormones, cytokkines and growth factors.J Endocrinol 210:5-14.

Sioen I, Fierens T, Van Holderbeke M, Geers L, Bellemans M, De Maeyer M, Servaes K, Vanermen G, Boon PE, De Henauw S (2012) Phthaltes dietary exposure and food sources for Belgian preschool childern and adults. Environ Int 48:102-108.

Snejdrova E, Dittrich M (2012) Pharmaceutically used plasticizers. In: Luqman M (ed), Recent admvances in plasticizers. InTech, Rijeka, Croatia.

Somasundaram DB, Manokaran K, Selvanesan BC, Bhaskaran RS (2016) Impact of di-(2ethylhexyl) phthalate on the uterus of adult Wister rats. Hum Exp Toxicol 36:565-572.

Spencer TE, Bartol FF, Wiley AA, Coleman DA, Wolfe DF (1993) Neonatal porcine endometrial development involves coordinated changes in DNA synthesis, glycosaminoglycan distribution, and 3H-glucosamine labeling. Biol Reprod 48:729-740.

Spencer TE, Dunlap KA, Filant J (2012) Comparative developmental biology of the uterus: Insights into mechanisms and developmental disruption. Mol Cell Endocrinol 354:34-53.

Street ME, Angelini S, Bernasconi S, Burgio E, Cassio A, Catellani C, Cirillo F, Deodati A, Fabbrizi E, Fanos V, Gargano G, Grossi E, Iughetti L, Lazzeroni P, Mantovani A, Migliore L, Palanza P, Panzica G, papini AM, Parmigiani S, Predieri B, Sartori C, Tridenti G, Amarri S (2018) Current knowledge on endocrine disrupting chemicals (EDCs) from animal biology to humans, from pregnancy to adulthood: Highlights from a national Italian meeting. Int J Mol Sci 19:1647.

Su PH, Chen JY, Lin CY, Chen HY, liao PC, Ying TH, Wang SL (2014) Sex steroid hormone levels and reproductive development of eight-year-old children following in utero and environmental exposure to phthalates. PLOS One 9:e102788.

Tan J, Paria BC, Dey SK, Das SK (1999) Differential uterine expression of estrogen and progesterone receptors correlates with uterine preparation for implantation and decidualization in the mouse. Endocrinology 140:5310-5321.

Taylor KM, Chen C, Gray CA, Bazer FW, Spencer TE (2001) Expression of messenger ribonucleic acids for fibroblast growth factors 7 and 10, hepatocyte growth factor, and insulinlike growth factors and their receptors in the neonatal ovine uterus. Biol Reprod 64:1236-1246.

Tomic D, Frech MS, Babus JK, Symonds D, Furth PA, Koos RD, Flaws JA (2007) Effects of ER $\alpha$ overexpression on female reproduction in mice. Reprod Toxicol 23:317-325.

Tomonari Y, Kurata Y, David RM, Gans G, Kawasuso T, Katoh M (2006) Effects of di (2-ethylhexyl) phthalates (DEHP) on genital organs from juvenile common marmosets: I. Morphological and biochemical investigation in 65-week toxicity study. J Toxicol Environ Health 69:1651-1672.

Veeramachaneni DN, Klinefelter GR (2014) Phthalate-induced pathology in the foetal testis involves more than decreased testosterone production. Reproduction 147:435-442.

Ventrice P, Ventrice D, De Sarro G (2013) Phthalates: European regulation, chemistry, pharmacokinetic and related toxicity. Environ Toxicol Pharmacol 36:88-96.

Walker CL (2011) Epigenomic reprogramming of the developing reproductive tract and disease susceptibility in adulthood. Birth Defects Res A: Clin Mol Tertol 91:666-671.

Wang H, Eriksson H, Sahlin L (2000) Estrogen receptors alpha and beta in the female reproductive 
tract of the rat during the estrous cycle. Biol Reprod 63:1331-1340.

Wang Y, Zhu H, Kannan K (2019) A review of biomonitoring of phthalate exposures. Toxics 7:21.

Watkins DJ, Sánchez BN, Téllez-Rojo M, Lee JM, Mercado-García A, Blank-Goldenberg C, Peterson KE, Meeker JD (2017) Impact of phthalate and BPA exposure during in utero windwons of susceptibility on reproductive hormones and sexual maturation in peripubertal males. Environ Health 16:69.

Zamkowska D, Kanwacka A, Jurewicz J, Radwan M (2018) Environmental exposure to nonpersistent endocrine disrupting chemicals and smen quality: An overview of the current epidemiological enidence. Intern J Occupation Med Environ Health 31:377-414.

Zhou C, Gao L, Flaws JA (2017) Exposure to an environmentaly relevant phthalate mixtue causes transgenerational effects on female reproduction in mice. Endocrinology 158:1739-1754. 
